\title{
Core Gene Expression and Association of Genotypes with Viral Load in Hepatitis C Virus (HCV) - Infected Patients in Punjab, Pakistan
}

\author{
Muhammad F Bashir ${ }^{1,2}$, Muhammad S Haider ${ }^{3 \star}$, Naeem Rashid ${ }^{1}$ and Saba Riaz \\ 2,4 \\ ${ }^{1}$ School of Biological Sciences, University of the Punjab, ${ }^{2}$ Division of Molecular Pathology, Citi Lab and Research Centre, \\ Lahore, Pakistan. ${ }^{3}$ Institute of Agricultural Sciences, ${ }^{4}$ Department of Microbiology and Molecular Genetics, University of the \\ Punjab, Lahore, Pakistan
}

*For correspondence: Email: haider65us@yahoo.com; mfaisalsab@gmail.com; Tel: 00924299231847

Received: 18 April 2013

Revised accepted: 5 May 2013

\begin{abstract}
Purpose: To determine genotypic distribution, ribonucleic acid (RNA) RNA viral load and express core gene from Hepatitis C Virus (HCV) infected patients in Punjab, Pakistan.

Methods: A total of 1690 HCV RNA positive patients were included in the study. HCV genotyping was tested by type-specific genotyping assay, viral load, by real time polymerase chain reaction (PCR) and $\mathrm{HCV}$ core protein was expressed in E. coli. Antigenicity of core protein was confirmed by enzyme-linked immunosorbant assay (ELISA).

Results: Out of total 1690 serum samples, type-specific PCR fragments were observed in 1482 (87.69 $\%)$ of the samples. In both genders, genotype $3 a(55.44 \%)$ was most prevalent followed by $3 b$ (15.03 $\%), 1 a(6.98 \%)$ and $1 b$ (3.14 \%). Regionally, genotype 3a occurred most frequently in Jaranwala (59.72 $\%)$. Patients infected with genotype 3 had pre-treatment viral load values of 52.56, 15.79 and $31.65 \%$, while patients infected by other genotypes showed viral load values of $13.43,35.27$ and $51.3 \%$ for low, intermediate and high categories of viral load, respectively. ELISA showed that core protein possessed greater antigenicity.

Conclusion: HCV genotype $3 a$ is the most prevalent genotype in Punjab, although the distribution of HCV genotypes in eight cities of Punjab was not uniform. HCV core protein used to develop local screening assays may be more effective than current commercial assays.
\end{abstract}

Keywords: Hepatitis C, Antigenicity, Genotyping, Viral load, Core gene

Tropical Journal of Pharmaceutical Research is indexed by Science Citation Index (SciSearch), Scopus, International Pharmaceutical Abstract, Chemical Abstracts, Embase, Index Copernicus, EBSCO, African Index Medicus, JournalSeek, Journal Citation Reports/Science Edition, Directory of Open Access Journals (DOAJ), African Journal Online, Bioline International, Open-J-Gate and Pharmacy Abstracts

\section{INTRODUCTION}

The severity of HCV is well known all over the world. Prevalence of HCV is different in different geographical areas, which also depends on the different genotypes of HCV. These genotypes were developed from the high degree of HCV sequence variation. There are six major HCV genotype groups and seventy subgroups [1]. In certain geographic areas Genotypes 1, 2 and 3 are more prevalent compared to 4,5 and 6 which are present in other geographic areas. Genotypes 1 and 2 are predominantly present in the USA and Western Europe, genotype 4 found in Africa, genotype 5 in South Africa and genotype 3 in South East Asia, known genotypes do not have the same response to treatment strategies, so studying the geographic distribution of HCV genotypes is very helpful to 
plan treatment strategies [2]. The other prognostic indicator is the pretreatment HCV viral load which is helpful in treatment decisions. High viral load was observed in some genotypes like genotype 1 as compared to other genotypes. Association of viral load and genotypes are not extensively studied but some association studies give the idea that high viral load is difficult to treat than low viral load [3]. HCV virion is enveloped positive strand RNA virus. It consists of 10 viral proteins which are divided into structural and nonstructural proteins. Core is a structural multifunctional protein and it affects host cell functions, including apoptosis, HCV associatedsteatosis, immune cell functions, cell transformation, signal transduction, and transcriptional regulation leading to Hepatitis Cell Carcinoma [4].

Prevalence of $\mathrm{HCV}$ in Pakistan is $4.8 \%$ which is among the in the world countries [5]. Our study deals with the prevalence of $\mathrm{HCV}$ genotypes, viral load and expression of core gene in Punjab province of Pakistan. Punjab is the most populous province of Pakistan, with approximately $51.6 \%$ of the country's total population and 205344 total area in square kilometers [6]. This is the most developed, populous, and prosperous province in Pakistan. No study has been conducted in Punjab to evaluate the relationship between viral load and genotypes in HCV-infected patients. Since these two factors have significance in the treatment of patients, this study was conducted to determine genotypic distribution, RNA viral load and express core gene from HCV infected patients in Punjab, Pakistan .

\section{EXPERIMENTAL}

\section{Sample collection}

Between the years 2007 and 2010, serum samples were collected from HCV-infected patients visiting collection centers/sub-centers of Citi Lab and Research Center, Lahore, Pakistan from eight different cities of Punjab, Pakistan. Data sheets with demographic characteristics, age, marital status and address from participating patients were filled by a research assistant. Patients were informed about the study and they gave their consent to participate in the study. The study was approved by the Ethics Committee of Citi Lab and Research Centre, Lahore, Pakistan (approval ref no. CLRC-143/11) and international guidelines for human studies were followed [7].

\section{HCV RNA quantitation}

RT-PCR of HCV RNA was performed using Mini OpticonTM System BIO-RAD Thermal Cycler. HCV RNA extraction and quantification Kits were manufactured by AJ Roboscreen Germany. The kit shows a linear measurement between 6,000 to $6,000,000,000 \mathrm{IU} / \mathrm{ml}$ and can detect $<172$ copies/ml HCV RNA. Specimens yielding values more than upper limit were diluted 100 times, tested again, then results obtained were multiplied to this dilution factor to get the actual HCV RNA concentration in international units $/ \mathrm{ml}$.

\section{HCV genotyping}

HCV genotyping was performed with genotype specific primers based on PCR of Core region. cDNA was prepared with 50 ng of HCV RNA using 100 units of M-MuLV reverse transcriptase enzyme (Fermentas, Life Sciences, USA) at 37 ${ }^{\circ} \mathrm{C}$ for 50 minutes. For first round PCR amplification $2 \mu \mathrm{l}$ cDNA was used. As we had to detect different genotypes so type specific primers were divided into two groups on the basis of sizes of different bands so no genotype specific primers were of the same size in the same group on agarose gel. Each first round PCR specimen was used to perform two second round nested PCR amplifications. One with mix-1 primers and second with mix-2 primers in a reaction volume of $20 \mu \mathrm{l}$. Mix-1 had genotype specific primers for $1 b, 2 a, 2 b$ and $3 b$ genotypes and Mix-2 had genotype specific primers for genotypes 1a, 3a, 4, 5a and 6a. Second round PCR products were observed on $2 \%$ agarose gel to separate type specific PCR fragment. DNA size marker 50bp DNA ladder (Fermentas, USA) was run on each gel. HCV genotype for each sample was determined by genotype specific PCR band.

\section{Cloning of core gene HCV in expression vector pET21a (+)}

pET21a (+) and core gene cDNA of HCV was digested thoroughly with Xbal and Hindlll. The target gene and large fragment vector were purified by agarose gel electrophoresis. The 573bp target gene fragment was ligated with 5338bp linearized pET21a (+) plasmid vector by adding bacteriophage T4 DNA ligase overnight at $22{ }^{\circ} \mathrm{C}$ and stored at $-20^{\circ} \mathrm{C}$. The ligated product was transformed into E. coli, and was incubated in an LB agar plate containing ampicillin overnight at $37^{\circ} \mathrm{C}$. Eight bacterial colonies were individually transferred into $2 \mathrm{ml}$ of LB medium containing ampicillin in a loosely capped $15 \mathrm{ml}$ tube, and the culture was incubated overnight at $37^{\circ} \mathrm{C}$ with vigorous shaking. To confirm that the 
culture did contain the correct plasmid; we prepared a small amount of plasmid DNA and analyzed it by digestion with restriction enzymes and was also sequenced.

\section{Identification of expressed proteins}

Twelve percent sodium dodecyl sulfate polyacrylamide gel electrophoresis (SDS-PAGE) SDS-PAGE was used to identify the expressed proteins. The sample was prepared as follows: 1 $\mathrm{ml}$ of induced culture was centrifuged to collect the pellet, and the pellet was re-suspended and boiled for $5 \mathrm{~min}$ to lyse the bacteria with $2 \times \operatorname{SDS}$ loading buffer. After electrophoresis, the polyacrylamide gel was stained with Coomassie Brilliant Blue, and scanned to analyze the expression level of the recombinant protein. The recombinant protein was used as antigen to test control positive sera by ELISA.

\section{Statistical analysis}

Data were analyzed using SPSS, version 16. The results for all variables were given in the form of rates (\%). Chi-Square or Fisher's exact test was applied to calculate $p$-value. $P$-values < 0.05 were considered significant.

\section{RESULTS}

The studied sample population comprised of $1690 \mathrm{HCV}$ infected patients. Out of which 1166 (69 \%) were males and $524(31 \%)$ were females. In both genders, genotype 3a (55.44 \%) was most prevalent followed by $3 b(15.03 \%)$ and 1a $(6.98 \%)$, in female patients genotype 3a was $54 \%$ followed by $3 \mathrm{~b}(18.51 \%), 1 \mathrm{a}(4.96 \%), 1 \mathrm{~b}$ $(4.39 \%)$ and $2 \mathrm{a}(0.38 \%)$ while in male patients genotype $3 a$ was $56.08 \%$ followed by $3 b$ (13.46 $\%)$, 1a (7.89\%), 1b (2.57\%) and $2 \mathrm{a}(0.26 \%)$. Mixed genotype percentage in female patients was $9.35 \%$ while in males it was $5.66 \% .12 .30$ $\%(n=208)$ cases could not be genotyped. Data showed that HCV genotypes 1a, 3a and 3b (pvalue $<0.05$ ) had statistically significant variation between both genders whereas genotypes $1 \mathrm{~b}$, $2 a$ and mixed $(p>0.05)$ genotypes were statistically insignificant (Table 1).

Genotype distribution of HCV infected patients of different cities of the most populated province of Pakistan was evaluated (Table 2). Out of 617 $\mathrm{HCV}$ isolates of Lahore most frequent genotype was $3 a$ in $351(56.82 \%)$ patients followed by $3 b$ with $90(14.59 \%)$ patients. 1a in Lahore was identified in $47(7.62 \%)$ patients followed by $1 \mathrm{~b}$ in $17(2.76 \%)$. Only one isolate was identified of genotype 2a from Lahore. 46 (7.46\%) patients

Table 1: Gender-wise genotype distribution in HCV-infected patients of Punjab ( $n=1690)$

\begin{tabular}{lcccccccc}
\hline Genotype & \multicolumn{2}{c}{ Male } & \multicolumn{2}{c}{ Female } & \multicolumn{2}{c}{ Total } & Gender \\
\hline Subtype & Frequency & $\%$ & Frequency & $\%$ & P-value & Frequency & $\%$ & Ratio \\
\hline Genotype 1 & 122 & 10.46 & 49 & 9.35 & & 171 & 10.12 & 2.49 \\
1a & 92 & 7.89 & 26 & 4.96 & 0.000 & 118 & 6.98 & 3.54 \\
1b & 30 & 2.57 & 23 & 4.39 & 0.336 & 53 & 3.14 & 1.3 \\
Genotype 2 & 3 & 0.26 & 2 & 0.38 & & 5 & 0.3 & 1.5 \\
2a & 3 & 0.26 & 2 & 0.38 & 0.665 & 5 & 0.3 & 1.5 \\
Genotype 3 & 811 & 69.6 & 380 & 72.52 & & 1191 & 70.47 & 2.13 \\
3a & 654 & 56.08 & 283 & 54 & 0.000 & 937 & 54.44 & 2.31 \\
3b & 157 & 13.46 & 97 & 18.51 & 0.000 & 254 & 15.03 & 1.61 \\
Mixed Genotype & 66 & 5.66 & 49 & 9.35 & 0.113 & 115 & 6.8 & 1.34 \\
Undetermined & 164 & 14.06 & 44 & 8.4 & 0.000 & 208 & 12.3 & 3.73 \\
Total & 1166 & 69 & 524 & 31 & & 1690 & 100 & 2.22 \\
\hline
\end{tabular}

Table 2: Distribution of genotypes of HCV isolates from different cities of Punjab, Pakistan ( $n=1690)$

\begin{tabular}{lcccccccc}
\hline City & $\mathbf{1 a}$ & $\mathbf{1 b}$ & $\mathbf{2 a}$ & $\mathbf{a} \mathbf{3 a}$ & $\mathbf{3 b}$ & Mixed & UN & Total \\
\cline { 2 - 8 } Lahore & $47(7.62)$ & $17(2.76)$ & $1(0.16)$ & $351(56.82)$ & $90(14.59)$ & $46(7.46)$ & $65(10.53)$ & 617 \\
Faisalabad & $19(5.89)$ & $08(2.49)$ & $0(0)$ & $180(55.72)$ & $29(8.97)$ & $33(10.21)$ & $54(16.72)$ & 323 \\
Gojra & $19(8.71)$ & $05(2.29)$ & $1(0.46)$ & $124(56.89)$ & $50(22.93)$ & $02(0.92)$ & $17(7.80)$ & 218 \\
Shakarghar & $12(10.43)$ & $02(1.74)$ & $01(0.87)$ & $65(56.53)$ & $24(20.86)$ & $4(3.48)$ & $7(6.09)$ & 115 \\
Dipalpur & $06(3.65)$ & $09(5.48)$ & $01(0.62)$ & $77(46.95)$ & $21(12.80)$ & $16(9.76)$ & $34(20.73)$ & 164 \\
Pir Mahal & $05(4.54)$ & $09(8.18)$ & $01(0.90)$ & $62(56.36)$ & $15(13.64)$ & $06(5.45)$ & $12(10.91)$ & 110 \\
Darya khan & $4(5.63)$ & $2(2.82)$ & $0(0)$ & $35(49.30)$ & $17(23.94)$ & $04(5.63)$ & $09(12.68)$ & 71 \\
Jaranwala & $06(8.33)$ & $01(1.39)$ & $0(0)$ & $43(59.72)$ & $08(11.11)$ & $04(5.56)$ & $10(13.89)$ & 72 \\
p-value & 0.000 & 0.000 & IS & 0.0000 & 0.0000 & 0.000 & 0.000 & \\
\hline Note: UN = undetermined:percentages (\%) in parenthesis; IS insignificant &
\end{tabular}


were infected by more than one HCV genotypes in Lahore. $65(10.53 \%)$ isolates were undetermined. From Faisalabad 323 patients were genotyped and their distribution was observed as $180(55.72 \%)$ as $3 a, 29(8.97 \%)$ as $3 \mathrm{~b}, 19(5.89 \%)$ as $1 \mathrm{a}, 8(2.49 \%)$ as $1 \mathrm{~b}$ and 33 $(10.21 \%)$ with mixed genotype. 218 patients of Gojra had depicted genotypic prevalence as 124 $(56.89 \%)$ were identified as 3a while $50(22.93$ $\%$ as $3 b$, 1a was observed in 19 (8.71\%) patients and $1 \mathrm{~b}$ in only $05(2.29 \%)$ patients, 17 $(7.80 \%)$ patients were coinfected. $115 \mathrm{HCV}$ infected patients from Shakargarh had shown genotypic distribution as 65 (56.33\%) confirmed as $3 \mathrm{a}, 24(20.86 \%)$ as $3 \mathrm{~b}, 12(10.43 \%)$ as $1 \mathrm{a}$, $02(1.74 \%)$ as $1 \mathrm{~b}$ and $04(3.48 \%)$ as mix genotype. From Dipalpur 164 patients had shown genotypic distribution as; 77 (46.95\%) as 3a, 21 $(12.80 \%)$ as $3 b, 06(3.65 \%)$ as $1 a, 09(5.48 \%)$ as $1 \mathrm{~b}$ and $16(9.76 \%)$ as mix genotype. Prevalence of genotype from $110 \mathrm{HCV}$ infected patients of Pir Mahal was observed as: 62 (56.36 $\%)$ as $3 a, 15(13.64 \%)$ as $3 \mathrm{~b}, 05(4.54 \%)$ as $1 \mathrm{a}$, $09(8.18 \%)$ as $1 \mathrm{~b}$ and $06(5.45 \%)$ as mix genotype. $12(7.29 \%)$ samples could not be genotyped. 71 genotyped patients of Darya Khan had shown genotypic distribution as; 35 (49.30 $\%)$ as $3 a, 17(23.94 \%)$ as $3 b, 4(5.63 \%)$ as $1 a$, $2(2.82 \%)$ as $1 \mathrm{~b}$ and $04(5.63 \%)$ were infected by more than 1 genotype.

From Jaranwala, 72 HCV infected patients had shown genotypic picture as: $43(59.72 \%)$ as $3 a$, $08(11.11 \%)$ as $3 \mathrm{~b}, 06(8.33 \%)$ as $1 \mathrm{a}$, only one patient as $1 \mathrm{~b}$ and $04(5.56 \%)$ patients as mix genotype. All the studied HCV genotypes (pvalue $<0.05)$ have statistically significant variation except $2 \mathrm{a}(p>0.05)$ for different cities of Punjab. The data of HCV genotype distribution in different age groups were arranged between $10+$ to $70+$ (Table 3). Genotype 3a was most prevalent in age group $30+(n=381,70.56 \%)$ followed by $20+(n=98,57.99 \%)$ and $50+(n=$ $161,50.16 \%)$. Overall variation of $\mathrm{HCV}$ genotypes with different age groups is significant $(p<0.05)$.
Viral load distribution was divided into three categories based on its viral load levels such as low $(<200,000 \mathrm{IU} / \mathrm{ml})$, intermediate $(200,001$ $600,000 \mathrm{IU} / \mathrm{ml})$ and high (>600,000 IU/ml). Male and female patients were divided into 3 categories of viral load as $487(41.77 \%)$ and 206 $(39.31 \%)$ low, $249(21.36 \%)$ and $115(21.95 \%)$ intermediate, $430(36.88 \%)$ and $203(38.74 \%)$ high respectively. Patients infected by Genotype 3 were grouped into three viral load categories as low 626 (52.56\%), intermediate 188 (15.79 $\%)$ and high $377(31.65 \%)$ respectively. Patients those were infected by other HCV genotypes were grouped into low, intermediate and high categories of viral load as 67 (13.43\%), 176 $(35.27 \%)$ and $256(51.3 \%)$ respectively. Viral load categories Genotype3 and Other for both genders are insignificant and for different cities of Punjab they are statistically significant for all cities except Darya Khan (Table 4).

\section{DISCUSSION}

$\mathrm{HCV}$ is a major threat of the century; this is because of the nature of this virus which makes it difficult to treat. It leads to develop in severe conditions like liver cirrhosis and hepato-cellular carcinoma and also responsible in making people carrier of HCV. In India about 12-13 million HCV carriers were reported. With the change in the type of genotype, length of treatment and dosage of antiviral therapy can be changed. Viral response to interferon therapy is changed with genotype, such as genotype 3 and 1 gives better response. So HCV genotypes were very critically evaluated. The genotype of HCV varies along with geographical areas such as genotype $3 a$ following genotype 1 was more prevalent in India in 2011 [8].

In the United States high prevalence of HCV subtypes $1 \mathrm{a}$ and $1 \mathrm{~b}$ are well documented. In Europe HCV types $1 \mathrm{~b}$ and 2, in Thailand,

Table 3: Age-wise HCV genotype/subtype distribution in Punjab, Pakistan $(n=1690)$

\begin{tabular}{ccccccccc}
\hline \multicolumn{7}{c}{ Genotypes/ subtypes } \\
\hline Age groups & $1 \mathrm{a}$ & $1 \mathrm{~b}$ & $2 \mathrm{a}$ & $3 \mathrm{a}$ & $3 \mathrm{~b}$ & Mixed & Undetermined & Total \\
\hline $10_{+}$ & $0(0)$ & $0(0)$ & $3(9.09)$ & $13(39.40)$ & $8(24.24)$ & $2(6.06)$ & $7(21.21)$ & 33 \\
\hline $20+$ & $13(7.69)$ & $10(5.9)$ & $0(0)$ & $98(57.99)$ & $13(7.69)$ & $9(5.32)$ & $26(15.38)$ & 169 \\
\hline $30+$ & $36(6.66)$ & $4(0.74)$ & $1(0.18)$ & $381(70.56)$ & $32(5.93)$ & $25(4.63)$ & $61(11.30)$ & 540 \\
\hline $40+$ & $26(5.09)$ & $13(2.53)$ & $0(0)$ & $238(46.39)$ & $136(26.50)$ & $37(7.21)$ & $63(12.28)$ & 513 \\
\hline $50+$ & $18(5.60)$ & $21(6.54)$ & $0(0)$ & $161(50.16)$ & $49(15.26)$ & $31(9.66)$ & $41(12.78)$ & 321 \\
\hline $60+$ & $11(13.92)$ & $5(6.33)$ & $1(1.27)$ & $35(44.30)$ & $11(13.93)$ & $9(11.39)$ & $7(8.86)$ & 79 \\
\hline $70+$ & $14(40.0)$ & $0(0)$ & $0(0)$ & $11(31.43)$ & $5(14.29)$ & $2(5.71)$ & $3(8.57)$ & 35 \\
\hline
\end{tabular}

Note: \% in parenthesis 
Table 4: HCV viral load categories and their distribution by gender and genotypes in different cities of Punjab, Pakistan

\begin{tabular}{|c|c|c|c|c|c|c|c|c|}
\hline & & $\mathrm{HC}$ & J viral I & ad & & & & \\
\hline \multirow[t]{3}{*}{ City } & & $<200,000$ & $\begin{array}{c}I U / m I \\
(\%)\end{array}$ & $\begin{array}{r}200,001- \\
600,000\end{array}$ & $\begin{array}{c}I U / m I \\
(\%)\end{array}$ & $>600,000$ & $\begin{array}{c}I U / m I \\
(\%)\end{array}$ & $P$-value \\
\hline & Males & 487 & 41.77 & 249 & 21.36 & 430 & 36.88 & \\
\hline & Females & 206 & 39.31 & 115 & 21.95 & 203 & 38.74 & 0.630 \\
\hline \multirow[t]{2}{*}{ Punjab } & Genotype3 & 626 & 52.56 & 188 & 15.79 & 377 & 31.65 & \\
\hline & Other & 67 & 13.43 & 176 & 35.27 & 256 & 51.3 & $<0.001$ \\
\hline \multirow[t]{2}{*}{ Lahore } & Genotype3 & 220 & 49.89 & 77 & 17.46 & 144 & 32.65 & \\
\hline & Other & 19 & 10.8 & 37 & 21.02 & 120 & 68.18 & $<0.001$ \\
\hline \multirow[t]{2}{*}{ Faisalabad } & Genotype3 & 69 & 33.01 & 36 & 17.22 & 104 & 49.76 & \\
\hline & Other & 10 & 8.77 & 40 & 35.08 & 64 & 56.14 & $<0.001$ \\
\hline \multirow[t]{2}{*}{ Gojra } & Genotype3 & 126 & 72.41 & 8 & 4.59 & 40 & 22.99 & \\
\hline & Other & 11 & 25 & 26 & 59 & 7 & 15.9 & $<0.001$ \\
\hline \multirow[t]{2}{*}{ Shakargarh } & Genotype3 & 61 & 68.54 & 17 & 19.1 & 11 & 12.36 & \\
\hline & Other & 6 & 23.07 & 7 & 26.92 & 13 & 50 & $<0.001$ \\
\hline \multirow[t]{2}{*}{ Depalpur } & Genotype3 & 58 & 59.18 & 10 & 10.2 & 30 & 30.61 & \\
\hline & Other & 4 & 6.06 & 35 & 53.03 & 27 & 40.91 & $<0.001$ \\
\hline \multirow[t]{2}{*}{ Peer Mahal } & Genotype3 & 49 & 63.64 & 19 & 24.68 & 9 & 11.69 & \\
\hline & Other & 7 & 21.21 & 16 & 48.48 & 10 & 30.3 & $<0.001$ \\
\hline \multirow{2}{*}{$\begin{array}{l}\text { Darya } \\
\text { Khan }\end{array}$} & Genotype3 & 15 & 28.84 & 16 & 30.76 & 21 & 40.38 & \\
\hline & Other & 5 & 26.31 & 7 & 36.84 & 7 & 36.84 & 0.889 \\
\hline \multirow[t]{2}{*}{ Jaranwala } & Genotype3 & 28 & 54.9 & 5 & 9.8 & 18 & 35.3 & \\
\hline & Other & 5 & 23.81 & 8 & 38.1 & 8 & 38.1 & 0.002 \\
\hline
\end{tabular}

genotypes 1a, 6a, and 3a, in Hong Kong, genotype $6 \mathrm{a}$ while in China subtype $1 \mathrm{~b}$ is predominant [9]. When data were analyzed in different cities of Punjab Pakistan. It was observed that Genotype 3a was most dominating among other genotypes with a prevalence rate of $55.44 \%$ followed by $3 b(15.03 \%)$, 1 a $(10.12 \%)$, $1 \mathrm{~b}(3.14 \%)$ and $2 \mathrm{a}(0.3 \%)$. No particular difference was noticed in prevalence of genotype based on gender classification. Maximum gender ratio was for genotype 1a which was 3.54 while the minimum was 1.30 which was for genotype 1b. Female patients were $3.69 \%$ more affected than males in infection caused by mixed genotypes. Here, regional difference was observed in different cities of Punjab, as genotype $3 \mathrm{a}$ had shown $12.77 \%$ higher prevalence in Jaranwala $59.72 \%$ than Dipalpur $46.95 \%$, while patients of Darya Khan $23.94 \%$ were found to be $14.97 \%$ more infected by genotype $3 b$ than Faisalabad $8.97 \%$. Genotype 1a was found to be $6.78 \%$ more prevalent in Shakargarh $(10.43 \%)$ than Dipalpur $(3.65 \%)$. Genotype 1b was most prevalent in Pir Mahal $8.18 \%$. Patients infected by mixed genotype had shown highest prevalence in Dipalpur (18.92\%), whereas only two patients were coinfected in Gojra out of 218 studied patients. Ahmad et al [1] reported genotype 3a was 55.9 \% in Lahore. There is a shift in genotype distribution with increasing prevalence in genotypes $3 \mathrm{a}, 1 \mathrm{a}$ and 4 in Pakistan and some other countries due to migration [10]. It was found that HCV male patients were more affected than females which, also relates to data of a study conducted at the Jinnah Postgraduate Medical Centre, Karachi [11]. The results were analyzed according to age groups of patients in association of different HCV genotype. Patients of age group $30+(70.56 \%)$ had shown the highest infection rate of HCV genotype 3a. Genotype 3b had shown highest infection rate in age group $40+(26.50 \%)$ and had least infected to patients of age group 30+ (5.93\%). Genotype 1a had infected $40 \%$ patients of age group 70+ and had not infected any person of age group 10+. Genotype $1 \mathrm{~b}$ had victimized $6.54 \%$ patients of age group $50+$ and age groups $10_{+}$, and $70_{+}$were safe from this virus. Prevalence of coinfection was highest in age group $60+$. It was reported that people $<40$ years of age were more affected with HCV [11;12]. In contrast Muhammad et al, [13] reported that the high HCV prevalence rate in Pakistan was found in old age group people. Here it was observed that genotype 1 is more prevalent in old age (70+) patient group while $3 a$ in $30+$ and $3 \mathrm{~b}$ in $40+$ age group. It is therefore suggested that evolution of different genotypes according to age group of patients should be studied further with large sample size. Although the significant relation was found in genotype distribution of HCV, age and gender, which is also documented in several studies [12]. The other significant feature is viral load titers which 
is a great prognostic indicator that helps in treatment decisions. Actually patients with high viral load present a poor response to interferon therapy than those with low viral titers. No particular difference in viral loads was observed among both genders as low titers had been shown by $41.77 \%$ males and $39.31 \%$ females, while intermediate titers were analyzed in almost $21 \%$ patients of both genders and high viral load titers were shown by $36.88 \%$ males and $38.74 \%$ females. But significant difference in viral loads was observed in patients infected by genotype 3 and others. Patients infected by genotype 3 and others. Patients infected by genotype 3 had shown $39.13 \%$ more viral load titers in low category than patients infected by other genotypes. On the other hand patients infected by other genotypes had shown $19.65 \%$ more viral loads titers in high category than patients infected by genotype 3 . When data were analyzed in term of viral load in different cities of Punjab it was observed that maximum percentages of patients victimized by genotype 3 were exhibiting low HCV RNA titers were in Shakargarh $68.54 \%$. Association of HCV genotypes and viral load remains point of discussion [8]. Some studies showed a close association of high viral load with advanced liver stage and some showed no relation with viraemia [14].

Here the core gene fragment of $\mathrm{HCV}$ genome was reversed transcribed and amplified successfully from the serum of patients from Punjab province of Pakistan. The fragment was sequenced and highly expressed in E.coli. (Figure 5) The results of ELISA showed greater antigenicity of the recombinant protein, which demonstrated good prospects of using protein as an antigen to detect HCV antibodies. The nucleotide sequence homology analysis indicates the $\mathrm{HCV}$ isolates in this study (FR851292) belong to HCV core gene like Japan (D14309) and USA (EU099417). Previously this type of $\mathrm{HCV}$ was already isolated from this region [15]. This gives the idea that for endemic $\mathrm{HCV}$ this ELISA based kit method is much better because of local recombinant protein [16].

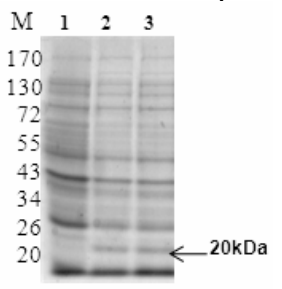

Figure 5: SDS PAGE analysis of un induced (lane 1) and induced in E. coli cells carrying HCV core gene.

Lane 1: E.coli containing pET21a (+), un induced.

Lane 2-3: E. coli containing pET21a(+), induced.

\section{CONCLUSION}

The study indicates that genotype 3 is the predominant genotype in Punjab, Pakistan followed by genotype1. Baseline viral load is significantly high in patients with other genotypes (1a, 1b, 2a, 3b, mixed genotypes and undetermined genotypes) compared to genotype 3. Regional differences also exist for genotypes. Moreover, we have successfully expressed recombinant $\mathrm{HCV}$ core antigen. This antigen used to develop local screening assay may be more effective than current commercial assays.

\section{ACKNOWLEDGEMENT}

This study was supported by Higher Education Commission of Pakistan.

\section{REFERENCES}

1. Ahmad W, ljaz B, Javed TF, Jahan S, Shahid I, Khan FM, Hassan S. HCV genotype distribution and possible transmission risks in Lahore, Pakistan. W. J. Gastrol. 2010; 16: 4321-4328.

2. George $M$, Lauer MD, Bruce D, Walker MD. Hepatitis $C$ virus infection. 2001; N. Engl. J. Med. 1: 41-52.

3. Husain A, Malik FA, Nagra H, Ehsan A, Ahmad Z, Abid M. Frequency of Different HCV Genotypes in Faisalabad. Anal. Punj. Med. Col. 2009; 3:19-22.

4. Fukutomi T, Zhou Y, Kawai S, Eguchi H, Wands JR, Li J. Hepatitis $C$ virus core protein stimulates hepatocyte growth: correlation with up regulation of wnt-1 expression. Hepatology. 2005; 41: 1096-1105.

5. Raja NS, Janjua KA. Epidemiology of hepatitis $C$ virus infection in Pakistan. J. Microbiol. Immunol. Infect. 2008; 41: 4-8.

6. Library of Congress, Federal Research Division. 2005 [cited 2008 Aug 18]. Available from:http://lcweb2.loc.gov

7. The NuGO Bioethics Guidelines on Human Studies, 2007 [cited 2008 Apr 20]. Available from http://nugo.dife.de/bot/index.

8. Chakravarti A, Dogra G, Verma $V$, Srivastava $P$. Distribution pattern of $\mathrm{HCV}$ genotypes and its association with viral load, Ind. J. Med. Res. 2011; 133: 326-331.

9. Liu JY, Lin H, Liu Y, Lee S, Chen Y, Hung C, Ko W, Huang $C$, Lai $C$, Chen $Y$, Shih $Y$, Chung $H$, Liang $S$, Lin $N$. Extremely High Prevalence and Genetic Diversity of Hepatitis C Virus Infection among HIV-Infected Injection Drug Users in Taiwan. Clin. Infect. Dis. 2008; 46: 1761-1768.

10. Ijaz T, Khan MA, Jafri SA, Ranjha FA, Mehmood KA, Imran M, Shahzad MK. Prevalence of Hepatitis $C$ Virus (HCV) Genotype $3 a$ in the Infected Population of Lahore, Pakistan. Int. J. Infect. Dis. 2008;1: S421-S425

11. Ahmed W, Arif A, Alam SE, Qureshi H. Changing trend of viral hepatitis - "A twenty one year report from Pakistan Medical Research Council Research Centre, Jinnah Postgraduate Medical Centre, Karachi. J. Pak. Med. Assoc. 2010; 60; 86-9.

12. Shah FU, Salih M, Malik IA, Hussain I. Increasing prevalence of chronic hepatitis and associated risk factors. Pak. J. Med. Res.2002; 41:46-50.

13. Muhammad $N$, Jan MA. Frequency of hepatitis " $C$ " in Buner, NWFP. J. Coll. Physicians. Surg. Pak.2005; 15: 11-14. 
14. Gretch $D$, Corey $L$, Wilson $J$, Rosa $C$, Willson $R$, Carithers R. Assessment of hepatitis $C$ virus RNA levels by quantitative competitive RNA polymerase chain reaction: high titer viraemia correlates with advanced stage of disease. J. Infect. Dis.1994; 169: 1219-25.

15. Khaliq S, Jahan S, ljaz B, Ahmad W, Asad S, Pervais A. Inhibition of Core gene of HCV 3a genotype using synthetic and vector derived siRNAs. Virol. J. 2010; 7: 318-326.

16. Waheed Y, Tahir S, Ahmad T, Qadri I. Sequence comparison and phylogenetic analysis of core gene of hepatitis $C$ virus from Pakistani population. Afr J. Biotechnol. 2010; 9: 4561-4567. 